\title{
Universities as Lifelong Learning Institutions: A New Frontier for Higher Education?
}

\author{
David Atchoarena
}

For half a century now, lifelong learning has provided — with more or less intensitythe philosophical and conceptual background in which education policies have been framed (Kejawa, 2017). When Paul Lengrand defined l'éducation permanente (1970), learning was conceived as part of a humanistic vision of the world, intrinsically characterized by fundamental values like human dignity, equal rights and social justice and respect for cultural diversity, as well as a sense of shared responsibility and a commitment to international solidarity. Today, these principles remain fundamental aspects of our common humanity and the enduring ideals of what learning can achieve.

While at international level, the Council of Europe, the European Commission and the OECD have played an active role in promoting lifelong learning, UNESCO shaped the vision and concept of 'lifelong learning for all', notably through the seminal works of two International Commissions led by Edgard Faure (1972) and Jacques Delors (1996). In the ensuing decades, the terminology of lifelong learning and its oft-used 'cradle to grave' metaphor remained, yet economic motives of competitiveness and labour market adaptation displaced attention from a humanistic vision to a materialist, market-driven perspective, the paradigm of a learning society giving way to the notion of a learning economy (Biesta 2006; Field 2000). Similarly, focus gradually shifted from the collective dimension of learning to an individual scale. Initially defined as a right to learning (United Nations 2016), lifelong learning often appeared as a duty which also had deep implications for the distribution of responsibilities between the state, social partners and individuals, and for designing funding schemes (Šimenc and Kodelja 2016). In these ways, the ambitious, inclusive conceptualizations expressed by Faure and Delors were compromised.

\footnotetext{
D. Atchoarena $(\bowtie)$

UNESCO Institute for Lifelong Learning, Hamburg, Germany

e-mail: d.atchoarena@unesco.org 
Adopted in 2015, the 2030 Agenda for Sustainable Development has reinvigorated the concept of lifelong learning and reconnected it with its humanistic origins, in particular with one stand-alone goal - SDG 4 - which calls on countries to "ensure inclusive and equitable quality education and promote lifelong learning opportunities for all'. Framing lifelong learning in relation to sustainable development repositioned the concept in a collective, long-term and holistic perspective, beyond the much narrower discourse that, for several decades, tended to dominate interpretation of the concept through specific policies and measures. Now, while working towards the 2030 Agenda for Sustainable Development, UNESCO is establishing a long-term vision for lifelong learning through its International Commission on the Futures of Education. Established in 2019 and chaired by Ethiopian President Ms Sahle-Work Zewde, the Commission is mandated to reimagine how knowledge and learning can shape the futures of humanity and will report its findings in 2021.

Over five decades, the concept of lifelong learning has been at various times articulated, repurposed, reduced, reframed and reinvigorated - the ideals at the heart of Lengrand's l'éducation permanente have been difficult to realize. Slow progress in changing education pathways and the actual experiences of learners can be explained in large part by the inertia of institutions. This is particularly true for universities, which have been historically slow in responding to the call to democratize access to higher learning. In line with this conservative behaviour, the general public have often regarded universities as elitist, particularly among disadvantaged groups who, for generations, have been deprived of learning opportunities.

Yet, increasingly, universities are redefining themselves as centres of lifelong learning by diversifying their provision, tailoring it to the knowledge and skills needed for the economy and those requested by non-traditional students (Milic 2013; Yang et al. 2015). They are thus gradually becoming key institutions for learning throughout life, opening their doors to adults who wish either to resume their studies or to acquire new knowledge and skills, whether to satisfy their taste for learning, enter or re-enter the labour market, or serve their community through voluntary work (Bernado et al. 2017). This trend mostly follows four interrelated dimensions: wider participation and flexibility; digitalization of learning; community engagement and global citizenship. Through those five dimensions, universities are revitalizing democratic participation in learning and beyond (Flemming 2006).

\section{Widening Participation, Promoting Inclusion and Building Flexible Learning Pathways}

Democratizing higher education and, eventually, society as a whole involves widening access to university studies. Widening access refers not only to an increase in the number of learners, but also to enhancing the chances of students with lower socioeconomic status to gain access to and complete quality education (European University Association 2008). Alternative pathways and financial support mecha- 
nisms are essential for widening access to those learners. Universities that promote inclusion refer to "widening", which refers to more diversity in the student population, and not just increasing the numbers of students (Smidt and Sursock 2011).

In aging societies, universities have to cater to the needs of a fast-growing population of older adults, with very different aspirations and learning needs. In some countries, low fertility rates have already led to a shrinking recruitment base for universities. This demographic decline constitutes a motivation for universities to find new "clients" and fields of action, such as targeting workers or senior citizens (Findsen and Formosa 2011). Furthermore, the COVID-19 pandemic has posed an existential challenge to some universities and, in the process, compelled them to quickly and dramatically widen access (Marinoni et al. 2020). Finding themselves unable to rely on the predictable traditional enrolments and additional income brought by international student mobility, universities have been looking to broaden their appeal to more diverse groups of learners who may remotely access their programmes.

The call for lifelong learning means a transition from the traditional role of educating young students coming directly from school to accommodating a diversity of learners entering, re-entering or late-entering higher education at different ages and at various phases of their personal and professional life (Stromquist and da Costa 2017). The concept of lifelong learning reflects a shift from delivery to demand, meaning that provision should be learner-centred (Cendon 2018). In that context, universities need to respond more flexibly to the needs of the individual learner.

Flexibility in learning pathways aims at offering learners different ways, such as accelerated programmes, apprenticeship schemes, open and distance learning, or blended programmes, to pursue their studies according to their needs. Hence, many universities have established preparatory programmes for candidates who did not complete higher secondary education or who graduated from vocational streams that do not normally grant access to university education. Successful completion of those preparatory programmes, usually one academic year, leads to a certification opening the door to higher education. In Europe, several countries, for example, France, Iceland, Ireland and the United Kingdom, have established such schemes.

The provision of flexible pathways also includes the availability of multiple entry and re-entry points, establishing links between formal and non-formal education programmes and institutions. Offering the possibility to study part-time together with the modularization of programmes are frequent strategies to diversify and widen access (Johannesen 2018).

While the dominant model in higher education remains the traditional full degree, universities offer more opportunities for non-traditional students, allowing diverse shorter, more flexible provision of learning, not necessarily leading to degrees (Jogi et al. 2015). In this context, there is need to introduce quality assurance of microcredentials as this is still rough territory. Hence, quality assurance agencies have an important role to play for promoting flexible pathways through developing standard recognition procedures. In addition, National Qualifications Frameworks and credit transfer systems form an important basis for flexible learning pathways and for the recognition, validation and accreditation of learning outcomes. 


\section{Leading and Adapting to the Digitalization of Learning}

The rapid development of online provision and blended courses offers a host of opportunities for lifelong learning (Carlsen et al., 2016, Cendon, 2018). Universities fully dedicated to open and distance learning, Massive Open Online Courses (MOOCs), mobile learning and open universities have transformed delivery patterns and contributed to widening access, despite their well-documented limitations (Knapper, 1983, Knapper 2009; Moreira et al. 2017).

The global COVID-19 crisis has provided further evidence of how technology can offer an alternative to conventional delivery models, as well as strengthening the diversification of courses to better address community needs. The pandemic has affected all universities around the world, with many of them being forced to close their premises and suspend on-campus teaching. Substituting on-campus teaching for online learning has sometimes been accompanied by measures to prevent dropout, notably by making laptops and $4 \mathrm{G}$ internet devices available to economically disadvantaged students (UNESCO 2020).

In addition to shifting to exclusively online learning activities, many universities have developed their open educational resources policy by enlarging open access to their digital resources, developing new contents, and making many resources available free-of-charge to the general public. In this context, traditional universities have often been forced to design more flexible formats, such as short-term courses and modular learning, and encouraged to reach out to new target groups, for example by catering to intergenerational groups of learners (Times Higher Education 2020). Hence, the pandemic is likely to contribute to the current growth in online provision, resulting in a diversification of content, including more open educational resources. While remotely reaching learners through online learning provision, the university sector seems to have simultaneously moved closer to its immediate environment in responding to the pandemic. There is evidence of universities responding more directly to the needs of the community. If sustained, such engagement could break down the stigma associated with online higher education, which is often deemed inferior to conventional studies by employers, and sometimes by quality assurance agencies. Establishing a parity of esteem between higher education qualifications obtained on campus and those achieved through digital learning continues to constitute a challenge.

\section{Universities as Drivers of Local Development}

Community engagement constitutes a significant part of universities' contribution to lifelong learning ( $\mathrm{Su}$ and Feng 1994). Engaged universities are connected to their ecosystem to work together on socially relevant issues. Responding to the sustainable development agenda ${ }^{1}$ universities are key institutions for promoting social

${ }^{1}$ Please see, for instance the work of the IAU at https://iau-aiu.net/HESD. 
innovations and the co-creation of solutions to major challenges, such as climate change, environmental degradation, rising inequalities, migration and global pandemics, among others (International Association of Universities 2019). Community engagement places particular attention to the needs of socially disadvantaged groups, which are often neglected (Preece 2017). This role is commonly conceptualized as the 'third mission' of universities, alongside education and research (Field et al. 2016).

An illustration of such partnerships is found in the emerging movement of learning cities and, specifically, the role that universities play in learning cities' strategies (Brennan and Cochrane 2019). Measures detailed in such documents include systems to support and incentivize academic staff and students to become more involved in the community and voluntary sector, as well as measures to enhance the local relevance of teaching and research (UNESCO 2015, 2017). This vision is consistent with the conceptualization of new knowledge production models based on networks and collaboration (Piazza 2018). Through community engagement, universities work with their immediate environment to respond to those challenges, linking local, often citizen-led initiatives to global challenges.

Driven by the principle of inclusion, learning cities advance policies and practices that foster sustainable development, social justice and active citizenship through lifelong learning. As such, they emerge as complex objects at the junction of education, economics, geography and political sciences (Facer and Magdalena Buchczyk 2019). Within the learning city, universities are often seen as key agents for the transfer of knowledge and the development of innovation networks. In particular, they are key to fostering processes of collective learning and innovation (Upton 2018). Furthermore, universities are often major economic powers at the local level-both as employers and investors - and are thus legitimate voices in the policy debate on skills needs, in attracting new industries, and more broadly, in urban regeneration and sustainable development at the local level.

\section{Engaging Universities for Global Citizenship}

The migration crisis has modified and introduced a human right dimension to the discussion on the internationalization of universities. Previously dominated by the "dictatorship of international ranking" and the global competition for attracting feepaying students, the debate has recently shifted in response to the deep international migration that currently affects humanity and one of its most tragic expression: the refugee crisis. This new concern has been amplified by media attention and the feeling that universities are failing refugees. While there are at least 79.5 million people displaced globally, including nearly 26 million refugees-around half of whom are under the age of 18 - only $3 \%$ of refugees have access to higher education (UNHCR 2020). This is a humanitarian catastrophe as well as a loss development potential for the planet. In recent years, the international community and an increasing number of universities in the world have been reflecting on ways to open the doors of higher 
education to refugees. Besides financial, physical and psycho-social barriers, the greatest obstacle is the lack of recognition, validation and accreditation of learning outcomes. Refugees are often unable to provide proof of their educational achievements and, even when they are able to do so, their previous studies are often not recognized in the host country.

At the global level, UNESCO has been engaged for a number of years in facilitating a consensus among member states to include specific provisions for refugees in the new regional conventions on the recognition of higher education qualifications. In 2019, the adoption of the UNESCO Global Convention on the Recognition of Higher Education Qualifications marked a pivotal moment. The new convention provides a global standardized process for improving mutual information on higher education systems and qualifications and a methodology for comparing university qualifications across countries. UNESCO has also contributed to the standardization of processes for assessing the qualifications of refugees. The so-called 'Qualifications Passport' is meant to guide the recognition, validation and accreditation of learning outcomes of refugees or vulnerable migrants who have completed or partially completed studies, in the absence of official educational documentation. This will provide credible and reliable information for accessing the job market or further studies.

At the institutional level, a number of universities have taken advantage of their autonomy by already introducing more flexible approaches to admission, using different ways to assess academic achievements in the absence of complete qualification documents. In addition, innovative approaches have been devised to deliver higher education to those who cannot reach university campuses, notably students in refugee camps. For instance, digital learning in higher education is being placed at the service of refugees in Jordan and Lebanon through online programmes. In partnership with UNHCR, universities are now promoting the concept of "university corridors" to give refugee students from war-torn countries the opportunity of continuing to pursue their studies abroad or online. As such, they are contributing to reinvent humanitarian responses and recognize the essential role that higher education plays for addressing the refugee crisis and for protecting the human rights of refugees, including their right to education.

While, for several decades, the discourse on skills has dominated the field of lifelong learning, attempts and progress are being made to broaden its focus to return to a holistic concept of lifelong learning. This changing perspective involves recognizing the role of decentralized learning networks. Within that context, the diversification of access modes and learning pathways, the rise of digital provision and open educational resources, the engagement of universities at the local level-including within learning cities-and their global social responsibility in responding to the refugee crisis are signs of a renewed mandate for the university sector. Through their contribution to lifelong learning, universities ${ }^{2}$ are responding to very deep changes and

\footnotetext{
${ }^{2}$ UIL and IAU launched in 2020 an international university survey on the contribution of universities to lifelong learning, the outcome of this work is meant to be presented at the 2022 UNESCO World Conference on Higher Education.
} 
transformation in our societies, including ageing, social inequalities, environmental sustainability, digitalization, migration and global pandemics. Such transformations pose huge challenges that need to be addressed through collective, participatory and decentralized processes which require and support active and global citizenship. Fostering these dynamics through lifelong learning may be a new frontier for universities.

\section{References}

Bernado, B. S., Audet, X. L. L., \& Isus, S. (2017). Determinants of user demand for lifelong learning in institutions of higher education. International Journal of Training and Development, 21(1), 145-166. https://doi.org/10.1111/ijtd.12101

Biesta, G. (2006). What's the Point of Lifelong Learning if Lifelong Learning Has No Point? On the Democratic Deficit of Policies for Lifelong Learning, European Educational Research Journal, Volume 5, Numbers 3 \& 4

Brennan, J. \& Cochrane, A. (2019). Universities: in, of, and beyond their cities, Oxford Review of Education, 45:2, 188-203, https://doi.org/10.1080/03054985.2018.1551198

Carlsen, A., Holmberg, C., Neghina, C., Owusu-Boampong, A. (2016) Closing the Gap: Opportunities for distance education to benefit adult learners in higher education. Germany: UNESCO Institute for Lifelong Learning.

Cendon, E. (2018). Lifelong Learning at Universities: Future Perspectives for Teaching and Learning. Journal of New Approaches in Educational Research, 7(2), 81-87. https://doi.org/10.7821/ naer.2018.7.320

European University Association. (2008). European Universities' Charter on Lifelong Learning. Retrieved from: https://eua.eu/downloads/publications/european\%20universities $\% 20$ charter\%20on\%20lifelong\%20learning\%202008.pdf (26.08.2020)

Facer, K. \& Magdalena Buchczyk, M. (2019) Towards a research agenda for the 'actually existing' Learning City, Oxford Review of Education, 45:2, 151-167, https://doi.org/10.1080/03054985. 2018.1551990

Field, J. (2000). Lifelong Learning and the New Educational Order. UK: Trentham Books, Ltd.

Field, J., Schmidt-Hertha, B., Wadenegger, A. (2016). Universities and Engagement, Routledge, New York.

Findsen, B., \& Formosa, M. (2011). Lifelong Learning in Later Life: A Handbook on Older Adult Learning. AW Rotterdam: Sense Publishers.

Flemming,T. (2006). The University and Democracy: Habermas, Adult Learning and Learning Society, Maynooth Philosophical Papers. January 2006

International Association of Universities (2019). Higher Education \& SDG 13 : Climate Action Through University Teaching, Research and Community Engagement, IAU.

Jogi, L., Karu, K., \& Krabi, K. (2015). Rethinking teaching and teaching practice at university in a lifelong learning context. International Review of Education, 61, 61-77. https://doi.org/10.1007/ s11159-015-9467-z

Johannesen, H. S. (2018). 'Back into your arms' - Exploring models for integrated university professional learning in a lifelong perspective. Widening Participation and Lifelong Learning, 20(2), pp. 96-121. https://doi.org/10.5456/WPLL.20.2.96

Kejawa, I.D. (2017). Life Long Learning: A Strategic Analysis of Education. International Journal of Current Research, 9(4), 1-19.

Knapper, K. (1983, 2009 online). Media and adult learning: A Forum: Lifelong learning and distance education. American Journal of Distance Education, 2(1), 63-72.

Lengrand, Paul (1970), Introduction á l'éducation permanente, UNESCO: Paris. 
Marinoni, G., van't Land, H. and Jensen, T. (2020). IAU Global Survey on the Impact of COVID-19 on Higher Education around the World, IAU.

Milic, S. (2013). The twenty-first Century University and the Concept of Lifelong learning. Australian Journal of Adult Learning, 53(1), 159-178.

Moreira, J.-A., Reis-Monteiro, A. and Machado, A. (2017), Higher education distance learning and e-learning in prisons in Portugal. Comunicar, 25(51), 39-49.

Piazza, R. (2018). Creating learning opportunities for the cities : community engagement and third mission in the university of Catania, in James, J., Preece, J., Valdés-Cotera, R. (2018). Entrepreneurial learning city regions, Springer.

Preece, J. (2017). University Community Engagement and Lifelong Learning. Palgrave Macmillan. https://doi.org/10.1007/978-3-319-56163-9

Šimenc, M., Kodelja, Z. (2016) Lifelong Learning_From Freedom to Necessity, Creative Education, 7, 1714-1721, https://doi.org/10.4236/ce.2016.712174

Smidt, H. and Sursock A. (2011) Engaging Lifelong Learning: Shaping Inclusive and Responsive Universities (SIRUS). Belgium: European University Association.

Stromquist, N. P., \& da Costa, R. B. (2017). Popular Universities: An Alternative Vision for Lifelong Learning in Europe. International Review of Education, 63, 725-744. https://doi.org/10.1007/ s11159-017-9662-1

Su, Y., \& Feng, L. (1994). Community Service as a Lifelong Learning Practice: Themes and Hypothesis. International Journal of Humanities and Social Science, 4(4), 219-226.

Times Higher Education (2020), When will lifelong learning come of age, Retrieved from: https://www.timeshighereducation.com/features/when-will-lifelong-learning-come-ofage (24.07.2020)

United Nations (2016), Report of the Special Rapporteur on the right to Education, A/71/358 General Assembly, New York

UNESCO (2020), Higher education institutions' engagement with the community, UNESCO COVID-19 Education Response, Education Sector issue notes Issue note $n^{\circ}$ 5.3, Retrieved from: https://data2.unhcr.org/en/documents/details/75890 (26.08.2020).

UNESCO Institute for Lifelong Learning (2015), Guidelines for Building Learning Cities, UIL, Hamburg, Germany.

UNESCO Institute for Lifelong Learning (2017), Learning Cities and the SDGs: A Guide to Action, UIL, Hamburg, Germany

UNHCR (2020). Figures at a Glance, Retrieved from: https://www.unhcr.org/figures-at-a-glance. html (26.08.2020)

Upton, S. (2018). Overcoming cultural resistance to city-regionalism: what role for universities, in James, J., Preece, J., Valdés-Cotera, R. (eds.), Entrepreneurial Learning City Regions, Springer.

Yang, J., Schneller, C. and Roche, S. (2015) The Role of Higher Education in Promoting Lifelong Learning. UIL, Hamburg, Germany.

David Atchoarena has been Director of the UNESCO Institute for Lifelong Learning since April 2018. He was previously Director of the Division for Policies and Lifelong Learning Systems at UNESCO, including higher education. Prior to working for UNESCO, including many years at the International Institute for Educational Planning as programme specialist and later on Team leader, Mr Atchoarena served as Chargé de Mission at the National Agency for Lifelong Education of the French Ministry of Education and as a project coordinator in the Ministry of Finance and Planning in Saint Lucia. 
Open Access This chapter is licensed under the terms of the Creative Commons Attribution 4.0 International License (http://creativecommons.org/licenses/by/4.0/), which permits use, sharing, adaptation, distribution and reproduction in any medium or format, as long as you give appropriate credit to the original author(s) and the source, provide a link to the Creative Commons license and indicate if changes were made.

The images or other third party material in this chapter are included in the chapter's Creative Commons license, unless indicated otherwise in a credit line to the material. If material is not included in the chapter's Creative Commons license and your intended use is not permitted by statutory regulation or exceeds the permitted use, you will need to obtain permission directly from the copyright holder. 